\title{
STRATEGI PENGELOLAAN PANGKALAN PENDARATAN IKAN (PPI) GEBANG KABUPATEN CIREBON UNTUK MENINGKATKAN KESEJAHTERAAN NELAYAN
}

\author{
Sri Hartanti ${ }^{1}$ \\ Rinda Noviyanti2 \\ Lina Warlina ${ }^{3}$ \\ ${ }^{1}$ Pemda Kab. Cirebon \\ 2,3 Universitas Terbuka \\ e-mail: tantikelautan15@yahoo.com
}

\begin{abstract}
Gebang Fish Landing Base (Gebang PPI) was built as a means for fishermen and fisheries businessin Gebang District, Cirebon Regency, in carrying out fisheries economic activities in an effort to improve welfare. This study aims to analyze the condition of the Gebang PPI facilities and the level of utilization by the community, as well as the potential of fisheries capture in Gebang. The next aim is to determine the strategy for managing the Gebang PPI in an effort to improve the fishermen welfare. The method used is descriptive qualitative method. Primary data are obtained through observation, interviews, questionnaires and surveys, while secondary data are obtained from relevant government agencies to analyze the level of the Gebang PPI utilization. Variables are measured using a Likert scale, while SWOT analysis is used to determine the management strategy. The results of the analysis show that the conditions of the Gebang PPI facilities and infrastructures are inadequate for the continuity of fisheries activities, as well as the level of utilization because fishermen prefer to transact outside the PPI. This condition is caused by capital ties between fishermen and intermediary/middlemen. The large potential of fisheries in the Gebang PPI does not guarantee the level of fishermen welfare, because fisheries economic transactions are still determined by intermediary/middlemen as capital owners. The results of the SWOT analysis show the position in Quadrant I, a very favorable situation. That is, Gebang PPI has the opportunity and strength so that it can take advantage of the opportunities that exist. The strategy that must be implemented is to support aggressive growth policies (growth oriented strategy). The strategy that can be implemented is to optimally utilize the existing potential to facilitate fisheries activities in Gebang, so as to provide benefits for increasing the income of Gebang fishermen.
\end{abstract}

Keywords: PPI, management strategy, fishermen welfare

\begin{abstract}
ABSTRAK
Pangkalan Pendaratan Ikan (PPI) Gebang dibangun sebagai sarana bagi nelayan dan pelaku perikanan di Kecamatan Gebang, Kabupaten Cirebon, dalam menjalankan aktivitas ekonomi perikanan sebagai upaya meningkatkan kesejahteraan. Penelitian ini bertujuan untuk menganalisis kondisi fasilitas PPI Gebang dan tingkat pemanfaatannya oleh masyarakat, serta potensi perikanan tangkap di Gebang. Selanjutnya menentukan strategi pengelolaan PPI Gebang dalam upaya meningkatkan kesejahteraan nelayan. Metode yang digunakan adalah metode deskriptif kualitatif. Data primer diperoleh melalui observasi,
\end{abstract}


wawancara, kuesioner dan survei, sedangkan data sekunder diperoleh dari instansi pemerintah yang terkait untuk menganalisis tingkat pemanfaatan PPI. Pengukuran variabel menggunakan skala Likert, sedangkan untuk menentukan strategi pengelolaannya menggunakan analisis SWOT. Hasil analisis menunjukkan bahwa kondisi sarana dan prasarana PPI Gebang kurang memadai bagi kelangsungan aktivitas perikanan, begitu juga dengan tingkat pemanfaatannya karena nelayan lebih memilih bertransaksi di luar PPI. Kondisi ini disebabkan oleh ikatan permodalan antara nelayan dengan bakul/tengkulak. Besarnya potensi perikanan di PPI Gebang tidak menjamin tingkat kesejahteraan bagi nelayan, karena transaksi ekonomi perikanan masih ditentukan oleh bakul/tengkulak sebagai pemilik modal. Hasil analisis SWOT menunjukkan posisi pada Kuadran I, merupakan situasi yang sangat menguntungkan. Artinya, PPI Gebang mempunyai peluang dan kekuatan sehingga dapat memanfaatkan peluang yang ada. Strategi yang harus diterapkan adalah mendukung kebijakan pertumbuhan yang agresif (growth oriented strategy). Strategi yang dapat diterapkan adalah memanfaatkan secara optimal potensi yang ada untuk memfasilitasi kegiatan perikanan di Gebang, sehingga memberikan manfaat bagi peningkatan pendapatan nelayan Gebang.

Kata kunci: PPI, strategi pengelolaan, kesejahteraan nelayan

Pengelolaan Pangkalan Pendaratan Ikan (PPI) yang baik dan optimalisasi dalam operasionalnya merupakan salah satu tolak ukur keberhasilan pembangunan perikanan tangkap. Keberadaan PPI semestinya dapat menimbulkan dampak pengganda bagi pertumbuhan ekonomi lainnya, yang pada gilirannya dapat meningkatkan kesejahteraan masyarakat. Pengembangan dan pembangunan pelabuhan perikanan dan atau Pangkalan Pendaratan Ikan dapat memajukan ekonomi di suatu wilayah dan sekaligus dapat meningkatkan penerimaan negara dan Pendapatan Asli Daerah (PAD) (Direktorat Prasarana Perikanan Tangkap dalam Suherman \& Dault, 2009).

PPI Gebang di Kabupaten Cirebon memiliki posisi yang cukup strategis dan representatif dalam potensinya memfasilitasi kegiatan ekonomi perikanan masyarakat di Kabupaten Cirebon. Gebang merupakan ikon perikanan Kabupaten Cirebon sebagai pusat kegiatan ekonomi perikanan di pantai Utara Jawa. Gebang memiliki kontribusi cukup besar dalam memenuhi kebutuhan perikanan di Kabupaten Cirebon dan daerah lain. Hal ini ditunjukkan oleh beragamnya industri skala kecil dan menengah perikanan di Gebang. Pemerintah daerah Kabupaten Cirebon melalui Peraturan Daerah Nomor 17 tahun 2009 menegaskan perlunya aktivitas pelelangan untuk meningkatkan pendapatan dan kesejahteraan nelayan. Ragam kegiatan ekonomi perikanan seperti industri pengolahan hasil perikanan dan pemasaran serta potensi pariwisata merupakan potensi pendukung bagi perkembangan sektor perikanan di Gebang.

Aktivitas lelang ikan pada sebuah Tempat Pelelangan Ikan (TPI) merupakan suatu hal yang paling penting bagi eksistensi PPI. Sejak dibangun pada tahun 2003, PPI Gebang tidak dimanfaatkan untuk penyelenggaraan pelelangan ikan. Oleh karenanya, diperlukan kajian mengenai kondisi PPI Gebang berikut fasilitas pokok dan pendukungnya, sejauh mana pengelolaannya, dan kondisi sosial ekonomi perikanan di Gebang. Selain itu, perlu dilakukan kajian atas faktor-faktor penyebab tidak adanya proses pelelangan ikan di TPI Gebang. Sehingga dari hasil evaluasi ini dapat dirumuskan alternatif langkah strategi pengelolaan yang tepat dan terpadu. 
Tujuan penulisan artikel ini adalah (1) Menganalisis kondisi fungsi dan fasilitas PPI Gebang (2) Menganalisis potensi dan aktivitas ekonomi perikanan di pesisir Gebang (3) Memformulasikan landasan strategi pengelolaan PPI bagi upaya meningkatkan kesejahteraan nelayan.

\section{METODE PENELITIAN}

Metode yang digunakan dalam penelitian ini adalah metode deskriptif kualitatif. Variabel yang diukur dan dinilai dalam penelitian ini, meliputi aspek daya dukung pelabuhan, aspek potensi perikanan tangkap, aspek ekonomi masyarakat pesisir Gebang dan aspek pengelolaan PPI Gebang. Pengambilan data dilakukan dengan observasi, wawancara, kuesioner, dan survei. Wawancara dilakukan secara terstruktur dan pengisian kuisioner atas beberapa orang responden yang sudah ditentukan, yaitu stakeholders dan pemegang otoritas yang terkait dengan PPI Gebang. Data sekunder dibutuhkan untuk mendukung evaluasi terhadap potensi, peran PPI, dan perkembangan perikanan tangkap, yang diperoleh dari instansi pemerintah setempat dan instansi terkait lainnya.

Analisis teknis terhadap kapasitas dari fasilitas-fasilitas yang ada di pelabuhan dilakukan secara deskriptif kuantitatif dan kualitatif. Untuk penentuan strategi digunakan analisis SWOT. Analisis ini didasarkan pada logika yang dapat memaksimalkan kekuatan (strength), peluang (opportunity), namun secara bersamaan dapat meminimalkan kelemahan (weakness) dan ancaman (threats) yang ada di PPI Gebang.

\section{HASIL DAN PEMBAHASAN}

\section{Analisis Kondisi dan Tingkat Pemanfaatan PPI Gebang}

Hasil pengamatan dan survei mengenai kondisi fasilitas yang berada di PPI Gebang dapat dijelaskan sebagai berikut (a) Fasilitas pokok yang terdiri dari (1) Lahan seluas10,88 hektar telah dimanfaatkan untuk kantor dan TPI. (2) Dermaga labuh PPI Gebang sepanjang $\pm 50 \mathrm{~m}$ dan lebar $8 \mathrm{~m}$. Struktur dermaga berupa beton bertulang dalam keadaan baik. (3) Alur pelayaran pada sungai Ciberes mengalami proses pendangkalan. (4) Kolam pelabuhan seluas \pm 22 hektar mengalami pedangkalan dan mulai mengering. (5) Penahan gelombang (Breakwater) ada di dua sisi, yaitu sisi Barat sepanjang $945 \mathrm{~m}$ (amblas sepanjang $117 \mathrm{~m}$ ), dan sisi Timur sepanjang $536 \mathrm{~m}$ dalam kondisi baik. Keduanya belum dilengkapi dengan rambu pelayaran. (6) Jalan komplek sebagian berupa jalan tanah, sebagian lagi berupa paving blok, hasil pembangunan tahun 2016. Drainase masih buruk, karena belum dibangun saluran drainase di komplek PPI. (b) Fasilitas fungsional meliputi (1) Kantor administrasi berada di lantai atas dari bangunan PPI seluas kurang lebih $300 \mathrm{~m}^{2}$. Kantor administrasi dalam kondisi baik, karena telah dilakukan rehab berat pada tahun 2016. (2) Tempat pelelangan ikan (TPI) dengan luas $700 \mathrm{~m}^{2}$ dalam kondisi baik, sebagai hasil rehab gedung pada tahun 2016. (3) Daya listrik yang tersedia di PPI Gebang adalah 900 watt, hanya dapat digunakan untuk penerangan di kantor dan kegiatan administrasi. (4) Instalasi air bersih bersumber dari pompa sumur air tawar dengan kapasitas 450 liter, hanya dapat digunakan untuk MCK. (5) Terdapat Solar Packed Dealer Nelayan (SPDN) berjarak kurang lebih 800 meter dari PPI. (6) Menara suar PPI Gebang tidak memiliki fasilitas navigasi pelayaran, komunikasi dan menara suar belum masuk dalam program kerja dan anggaran dinas terkait. (7) Tidak ada saranaTempat Pembuangan Sementara (TPS) dan Instalasi Pengolahan Air Limbah (IPAL), karena belum terakomodir dalam perencanaan anggaran dan program kerja dinas terkait. (8) Dock/slipway dan tempat perbaikan jaring belum ada. (9) Laboratorium pembinaan mutu belum ada. (c) Fasilitas penunjang terdiri dari (1) Pagar yang dibangun mengelilingi kawasan PPI dalam kondisi baik. (2) Mushola yang ada di PPI Gebang dengan luas $3 \times 4 \mathrm{~m}^{2}$ dalam kondisi rusak dan tidak layak. . (3) MCK di PPI berada dalam 
kondisi rusak, sempit, kotor, dan tidak layak pakai. (4) Tidak ada fasilitas mess di PPI Gebang Mekar, karena sebagian besar nelayan yang mendarat di sekitar PPI Gebang adalah nelayan lokal Gebang. (5) Ruang pertemuan berada di lantai atas, sedangkan untuk pertemuan nelayan menggunakan ruang TPI yang tidak dipergunakan untuk lelang. (6) Pabrik es dibangun tahun 2010 menggunakan dana APBN. (7) Fasilitas pengolahan hasil perikanan, cold storage belum ada.

Hasil skoring tingkat pemanfaatan fasilitas PPI menurut responden disajikan pada Tabel 1.

Tabel 1. Perhitungan Skor Tingkat Pemanfaatan PPI Gebang

\begin{tabular}{llrrrl}
\hline \multicolumn{1}{c}{ Fasilitas Ppi } & Total Skor & $\begin{array}{c}\text { Rata- } \\
\text { Rata }\end{array}$ & $\begin{array}{c}\text { Presentase } \\
\text { Nilai }\end{array}$ & Keterangan \\
\hline a. & FASILITAS POKOK & 156 & 2.23 & $45 \%$ & cukup \\
\hline 1 & Lahan PPI & 98 & 1.40 & $28 \%$ & kurang \\
2 & Dermaga sandar & 83 & 1.19 & $24 \%$ & kurang \\
3 & Kolam pelabuhan & 98 & 1.40 & $28 \%$ & kurang \\
4 & Pemecah gelombang (breakwater) & 157 & 2.24 & $45 \%$ & cukup \\
\hline 5 & Jalan komplek dan drainase & & & $\mathbf{2 7 \%}$ & \\
\hline b. & FASILITAS FUNGSIONAL & 93 & 1.33 & $27 \%$ & kurang \\
\hline 1 & Kantor administrasi & 82 & 1.17 & $23 \%$ & kurang \\
2 & Gedung TPI & 107 & 1.53 & $31 \%$ & kurang \\
\hline 3 & Instalasi listrik dan air & & & $\mathbf{2 6 \%}$ & \\
\hline c. & FASILITAS PENUNJANG & 116 & 1.66 & $33 \%$ & kurang \\
\hline 1 & Pagar keliling kawasan PPI & 83 & 1.19 & $24 \%$ & kurang \\
2 & Mushola dan MCK & 83 & 1.19 & $24 \%$ & kurang \\
3 & Ruang pertemuan & 80 & 1.14 & $23 \%$ & kurang \\
\hline 4 & Pabrik es & & & &
\end{tabular}

Keterangan: $0 \%-20 \%=$ sangat kurang

$21 \%-40 \%=$ kurang

$41 \%-60 \%=$ cukup

$61 \%-80 \%$ = baik

$81 \%-100 \%=$ sangat baik

Hasil wawancara dan analisis data memperlihatkan penyebab tidak dilakukannya proses lelang hasil tangkap di PPI Gebang adalah sebagai berikut (1) Sebagian besar nelayan yang melaut memiliki kendala dalam hal permodalan, sehingga menjalin kerjasama dengan bakul/tengkulak untuk memberikan modal secara mudah dan tidak prosedural. (2) Tidak ada kewenangan pihak lain seperti koperasi untuk menyelenggarakan lelang.(3) Rendahnya akses perbankan oleh nelayan. (4) Pendangkalan muara sungai dan kolam pelabuhan menghambat aktivitas nelayan.(5) Infrastruktur 
yang telah dibangun tidak sepenuhnya siap memfasilitasi nelayan. (6) Kurangnya personil petugas di PPI Gebang sehingga tidak dapat mengakomodir kegiatan perikanan maupun aktivitas nelayan di PPI.

\section{Evaluasi terhadap Potensi Perikanan Tangkap}

Hasil nilai produksi tangkapan nelayan yang didaratkan di muara desa Gebang Mekar dari tahun 2012 sampai dengan 2016 ditunjukkan pada Gambar 1.

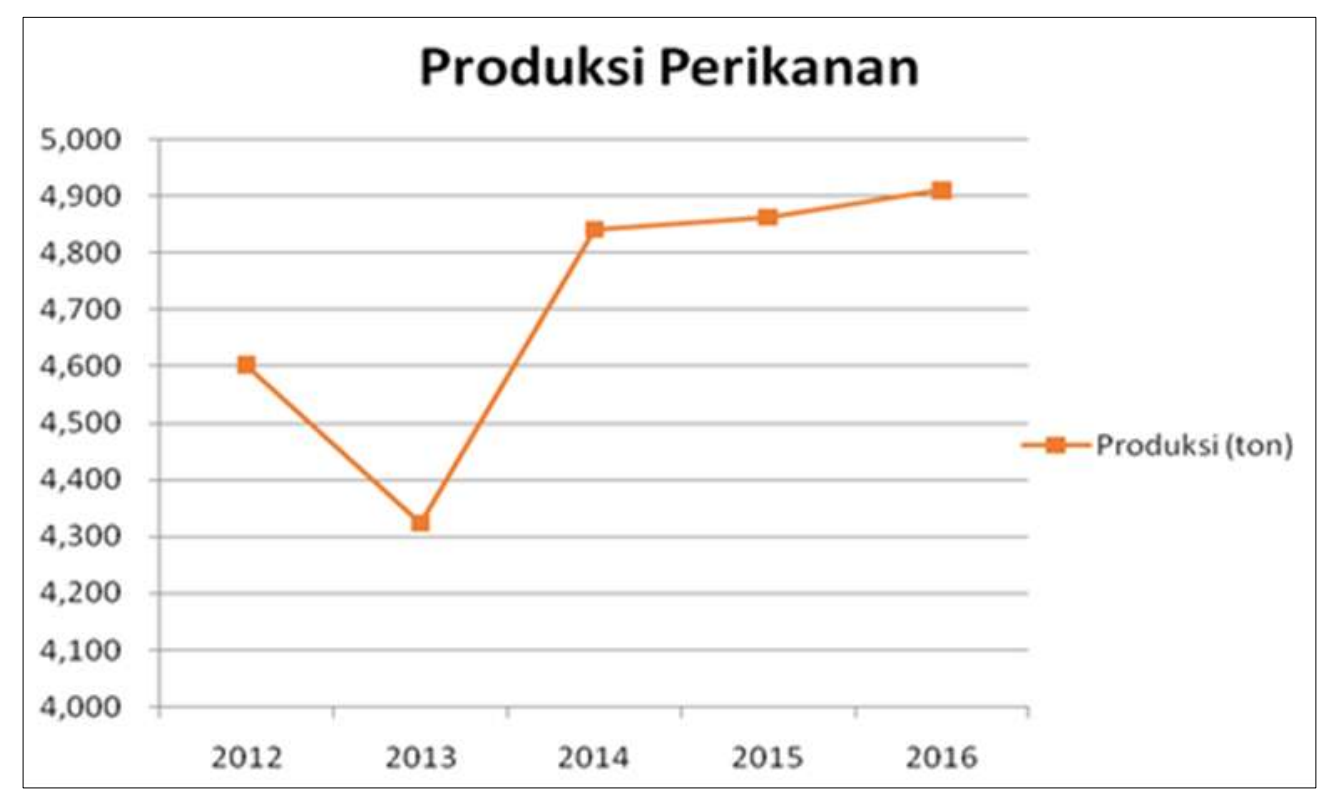

Gambar 1. Produksi perikanan dari tahun 2012 sampai dengan 2016

Kegiatan penangkapan ikan yang didaratkan di sepanjang muara Sungai Ciberes Desa Gebang Mekar didominasi oleh kapal kayu berukuran rata-rata 2-6 GT. Alat tangkap ramah lingkungan yang biasa digunakan adalah jaring kejer, jaring koncong (encircling gillnet), jaring insang tetap, rawai dasar, jaring insang hanyut, tramel net (jaring insang berlapis), bubu, pancing senggol, bagan, dan lain-lain. Alat tangkap tidak ramah lingkungan yang masih marak digunakan adalah payang, dogol, garok, dan arad. Hasil tangkapan adalah peperek, pari, belanak, kembung, manyung, bawal putih, kakap, tigawaja, udang dogol, udang krosok, cumi-cumi, sotong, rajungan, kerang darah, remis, kerang hijau. Usaha penangkapan ikan menjadi sandaran bagi perekonomian sebagian masyarakat pesisir Gebang dengan penghasilan per hari rata-rata Rp 75.000,- sampai dengan Rp150.000,- atau Rp 1.500.000,- hingga Rp 3.000.000,- per bulan.

\section{Kondisi Sosial Ekonomi Nelayan Gebang}

Tingkat pendidikan dan keterampilan nelayan di Gebang masih tergolong rendah. Tingkat pendidikan nelayan rata-rata adalah tingkat sekolah dasar hingga sekolah lanjutan pertama. Hal seperti ini juga terjadi di Desa Pasir Baru dan Cidadap Kabupaten Sukabumi (Noviyanti, Sugeng, Eko, Mulyono \& Budi, 2015), dimana jumlah nelayan menurun seiring dengan peningkatan 
pendidikan. Menurut Muflikhati, Hartoyo, Ujang, Ahmad \& Herien (2010), tingkat pendidikan nelayan lebih rendah dari non nelayan. Tingkat pendidikan yang rendah tersebut akan menghambat transfer teknologi penangkapan ikan, serta menciptakan pola kerja yang tidak disiplin dan kurang bertanggungjawab (Hendratmoko \& Marsudi, 2010). Nelayan Gebang cenderung memanfaatkan teknologi seadanya dan sulit untuk mengikuti perkembangan teknologi alat tangkap. Sebagian besar nelayan memilih profesinya karena faktor turun temurun, tidak memiliki keterampilan lain atau kemampuan di bidang lain.

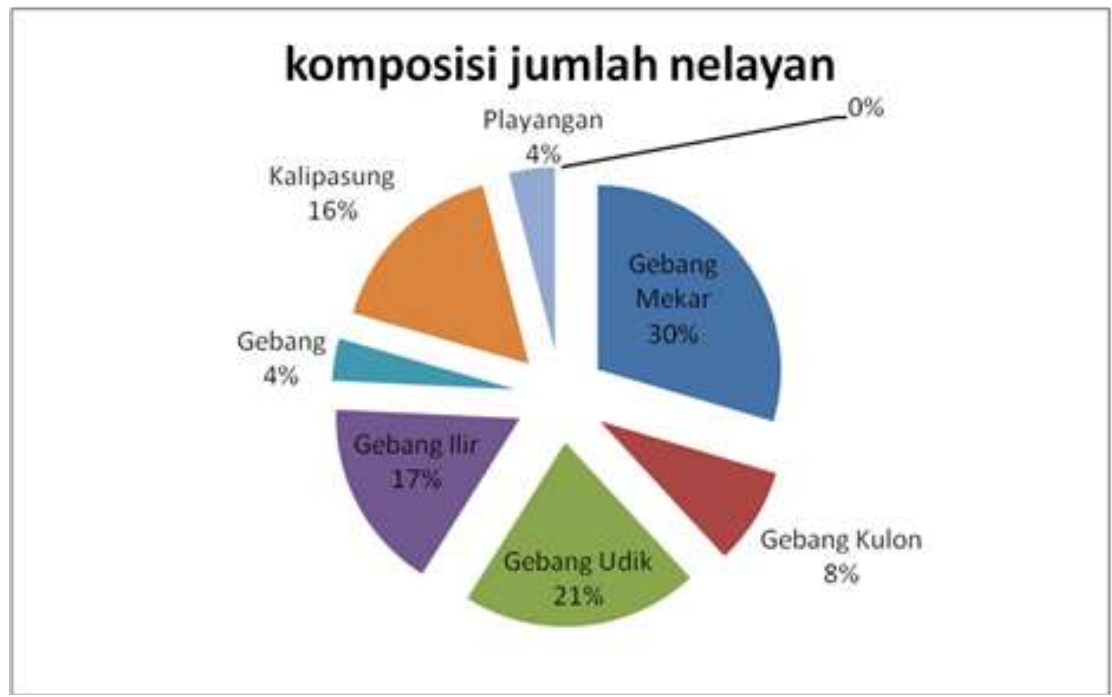

Gambar 2. Komposisi jumlah nelayan yang tersebar di Kec. Gebang, Kab. Cirebon tahun 2015

\section{Identifikasi Faktor Internal dan Eksternal}

Berdasarkan Tabel 1 terlihat bahwa pengelolaan PPI Gebang belum maksimal. Keadaan PPI Gebang yang jauh dari ideal membuat nelayan belum merasakan kehadiran PPI Gebang. Berikut ini adalah hasil identifikasi untuk faktor internal dan eksternal yang berperan dalam pengelolaan PPI Gebang. Selanjutnya dilakukan analisis SWOT untuk menganalisis faktor-faktor ekternal dan internal.

Tabel 2. Identifikasi Faktor Internal dan Eksternal Potensi PPI Gebang

\begin{tabular}{ll}
\hline \multicolumn{1}{c}{ Faktor Internal } & \multicolumn{1}{c}{ KakUATAN } \\
\hline \multicolumn{1}{c}{ KEKtor Eksternal } \\
\hline $\begin{array}{l}\text { 1. Kondisi fasilitas yang dimiliki PPI Gebang } \\
\text { (pokok, fungsional, dan penunjang) }\end{array}$ & 1. Dukungan masyarakat terhadap keberadaan PPI \\
2. Lokasi PPI yang strategis & 2. Dukungan pemerintah terhadap keberadaan PPI \\
$\begin{array}{l}\text { 3. Ketersediaan Sumber Daya Manusia } \\
\text { Perikanan }\end{array}$ & 3. Permintaan pasar terhadap produk perikanan \\
4. Jumlah armada kapal dan alat tangkap & 4. Potensi objek wisata \\
5. Tingkat produksi perikanan tangkap & 5. Pertumbuhan kelompok ekonomi perikanan \\
6. Master plan PPI Gebang & 6. Ketertarikan investor terhadap PPI Gebang \\
\hline
\end{tabular}


Tabel 2. Lanjutan

\begin{tabular}{|c|c|}
\hline Faktor Internal & Faktor Eksternal \\
\hline KELEMAHAN & ANCAMAN \\
\hline $\begin{array}{l}\text { 1. Buruknya sanitasi dan higienitas di } \\
\text { lingkungan PPI }\end{array}$ & 1. Faktor cuaca dan keamanan di laut \\
\hline 2. Rendahnya keamanan lingkungan PPI & $\begin{array}{l}\text { 2. Penggunaan alat tangkap yang tidak ramah } \\
\text { lingkungan }\end{array}$ \\
\hline 3. Pendangkalan kolam pelabuhan & 3. Konflik horizontal antara nelayan dan warga desa \\
\hline $\begin{array}{l}\text { 4. Kurangnya pelayanan dan proses lelang di } \\
\text { TPI }\end{array}$ & 4. Kerusakan lingkungan PPI Gebang \\
\hline $\begin{array}{l}\text { 5. Rendahnya tingkat pendidikan dan } \\
\text { keterampilan nelayan }\end{array}$ & $\begin{array}{l}\text { 5. Kuatnya ikatan permodalan antara nelayan dengan } \\
\text { bakul/tengkulak }\end{array}$ \\
\hline 6. Akses masuk area PPI yang sempit & 6. Pengaruh kenaikan harga BBM \\
\hline
\end{tabular}

Hasil perhitungan bobot dan skoring semua faktor internal dan internal, diperoleh nilai skor seperti pada Tabel 3.

Tabel 3. Sub Total dan Total Skor dari Faktor Strategis Internal

\begin{tabular}{|c|c|c|c|}
\hline Strategi & Indikator & Bobot & Skor \\
\hline Internal & Kekuatan & 0,49 & 1,416 \\
\hline \multirow[t]{2}{*}{ Internal } & Kelemahan & 0,51 & 0,750 \\
\hline & Total IFAS & 1,00 & 2,166 \\
\hline Eksternal & Peluang & 0,44 & 1,296 \\
\hline \multirow[t]{2}{*}{ Eksternal } & Ancaman & 0,56 & 0,989 \\
\hline & Total EFAS & 1,00 & 2,285 \\
\hline
\end{tabular}

Hasil skoring terhadap faktor-faktor yang berpengaruh terhadap pengelolaan PPI Gebang diperoleh bahwa faktor-faktor eksternal $(2,285)$ sedikit lebih berpengaruh dibandingkan dengan faktor-faktor internalnya $(2,166)$. Dengan demikian, dapat dikatakan bahwa keberadaan PPI Gebang dipengaruhi baik oleh faktor internal maupun eksternal.

\section{Analisis Rancangan dan Strategi Pengelolaan}

Analisis ini ditekankan pada rancangan dan penyusunan skala prioritas pengelolaan berdasarkan susunan matriks strategi SO (manfaatkan potensi untuk meraih peluang), strategi WO (mengatasi kelemahan untuk meraih peluang), strategi ST (manfaatkan potensi untuk menghadapi ancaman) dan strategi WT (minimalkan kelemahan untuk bertahan dari ancaman) (Rangkuti, 2016). Selanjutnya dilakukan rancangan strategi pengelolaan, yaitu menyusun rancangan pengelolaan pada analisis matriks SWOT berdasarkan analisis kualitatif dan kuantitatif faktor IFAS-EFAS sebelumnya. Dari hasil analisis tersebut disusun 6 faktor kekuatan (S) dan 6 faktor kelemahan (W) serta 6 faktor peluang (O) dan 6 faktor ancaman (T). Pada Tabel 4 dapat ditemukan 4 set strategi pengelolaan yang terdiri dari 12 buah strategi. 
Tabel 4. Analisis Matrik SWOT Pengelolaan PPI Gebang

\begin{tabular}{|c|c|c|}
\hline EFAS & \begin{tabular}{ll}
\multicolumn{1}{c}{ Kekuatan (Strength) } \\
1. Kondisifasilitas yang dimiliki PPI Gebang \\
(pokok, fungsional dan penunjang). \\
2. Lokasi PPI yang strategis. \\
3. Ketersediaan sumber daya manusia \\
perikanan. \\
4. Jumlah armada kapal dan alat tangkap. \\
5. Tingkat produksi perikanan tangkap. \\
6. Lahan PPI Gebang yang luas.
\end{tabular} & \begin{tabular}{ll} 
& \multicolumn{1}{c}{ Kelemahan (Weakness) } \\
1. & Buruknya sanitasi dan higienitas di \\
& lingkungan PPI. \\
2. & Rendahnya keamanan lingkungan PPI. \\
3. Pendangkalan kolam pelabuhan \\
4.
\end{tabular} \\
\hline $\begin{array}{l}\text { Peluang (Opportunity) } \\
\text { 1. Dukungan masyarakat terhadap } \\
\text { keberadaan PPI. } \\
\text { 2. Dukungan pemerintah terhadap } \\
\text { keberadaan PPI. } \\
\text { 3. Permintaan pasar terhadap produk } \\
\text { perikanan. } \\
\text { 4. Potensi objek wisata. } \\
\text { 5. Pertumbuhan kelompok ekonomi } \\
\text { Perikanan. } \\
\text { 6. Ketertarikan investor terhadap PPI } \\
\text { Gebang. }\end{array}$ & $\begin{array}{l}\text { Strategi S-O } \\
\text { 1. Pemanfaatan fasilitas PPI yang ada secara } \\
\text { optimum sebagai embrio dalam pelayanan } \\
\text { kegiatan penangkapan ikan. } \\
\text { 2. Perbaikan dan pembaharuan sarana dan } \\
\text { prasarana penangkapan sebagai upaya } \\
\text { peningkatan produksi perikanan tangkap. } \\
\text { 3. Penawaran kerjasama kepada investor } \\
\text { untuk memanfaatkan lahan mewujudkan } \\
\text { Master plan PPI. }\end{array}$ & $\begin{array}{l}\text { Strategi W-O } \\
\text { 1. Menjaga dan meningkatakan keamanan } \\
\text { di lingkungan PPI bersama-sama } \\
\text { dengan masyarakat. } \\
\text { 2. Perbaikan saluran pembuangan, } \\
\text { penyediaan air bersih, tempat sampah } \\
\text { dan pengolahan sampah. } \\
\text { 3. Penambahan personel PPI Gebang, } \\
\text { sehingga dapat memberikan pelayanan } \\
\text { yang maksimal kepada nelayan. } \\
\text { 4. Pemerintah daerah menunjuk Koperasi } \\
\text { untuk melaksanakan kegiatan } \\
\text { pelelangan, dengan mengupayakan dana } \\
\text { talangan serta pendampingan kegiatan } \\
\text { lelang dengan pendampingan } \\
\text { aparaturnya. }\end{array}$ \\
\hline 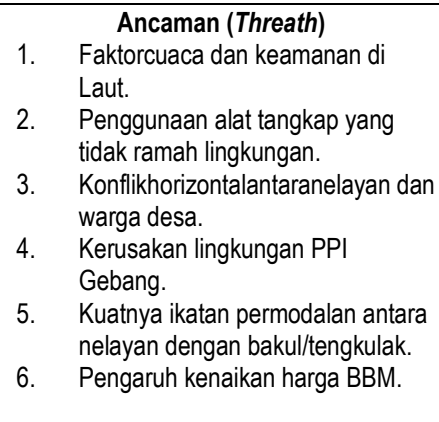 & $\begin{array}{l}\text { Strategi S-T } \\
\text { 1. Pembinaan dan pelatihan penggunaan } \\
\text { alat tangkap ramah lingkungan. } \\
\text { 2. Pembinaan dan Penegakan hukum dalam } \\
\text { hal ini Perda no. } 17 \text { Tahun } 2009 \text { tentang } \\
\text { retribusi TPI dan Peraturan Menteri KP } \\
\text { no.1 dan 2 Tahun 2015. }\end{array}$ & $\begin{array}{l}\text { Strategi W-T } \\
\text { 1. Memprioritaskan pekerjaan pengerukan } \\
\text { dalam rencana kerja dan anggaran rutin. } \\
\text { 2. Peningkatan peran pemerintah dan } \\
\text { masyarakat dalam mengelola PPI } \\
\text { Gebang, sehingga aset yang sudah } \\
\text { dibangun akan memberikan manfaat bagi } \\
\text { sebesar-besarnya kemakmuran nelayan } \\
\text { Gebang. } \\
\text { 3. Bekerjasama dengaan Dinas PU untuk } \\
\text { Percepatan pembangunan jalan lingkar } \\
\text { sebagai pengalihan akses awal yang } \\
\text { sempit. }\end{array}$ \\
\hline
\end{tabular}

\section{a. Penentuan Strategi Pengelolaan}

Penentuan strategi pengelolaan didasarkan pada posisi titik koordinat dan kuadran. Untuk menentukan prioritas strategi dilakukan penjumlahan bobot yang berasal dari keterkaitan antara unsur-unsur SWOT yang terdapat dalam suatu alternatif strategi. Jumlah bobot skor/nilai tersebut akan menentukan urutan prioritas alternatif strategi yang diperlukan untuk menyusun rencana strategi pengelolaan PPI Gebang.

Selanjutnya penentuan titik koordinat dan kuadran sebagai berikut.

$$
\begin{array}{lll}
\text { (Skor Kekuatan - Skor Kelemahan } & ; & \text { Skor Peluang - Skor Ancaman) } 2 \\
\frac{(1,416-0,750}{2} ; \quad \frac{1,296-0,989)}{2}= & (0,333 ; 0,154) \approx(0,33 ; 0,15)
\end{array}
$$


Koordinat $X, Y=0,33 ; 0,15$ mempunyai nilai positif dan masuk pada kuadran I

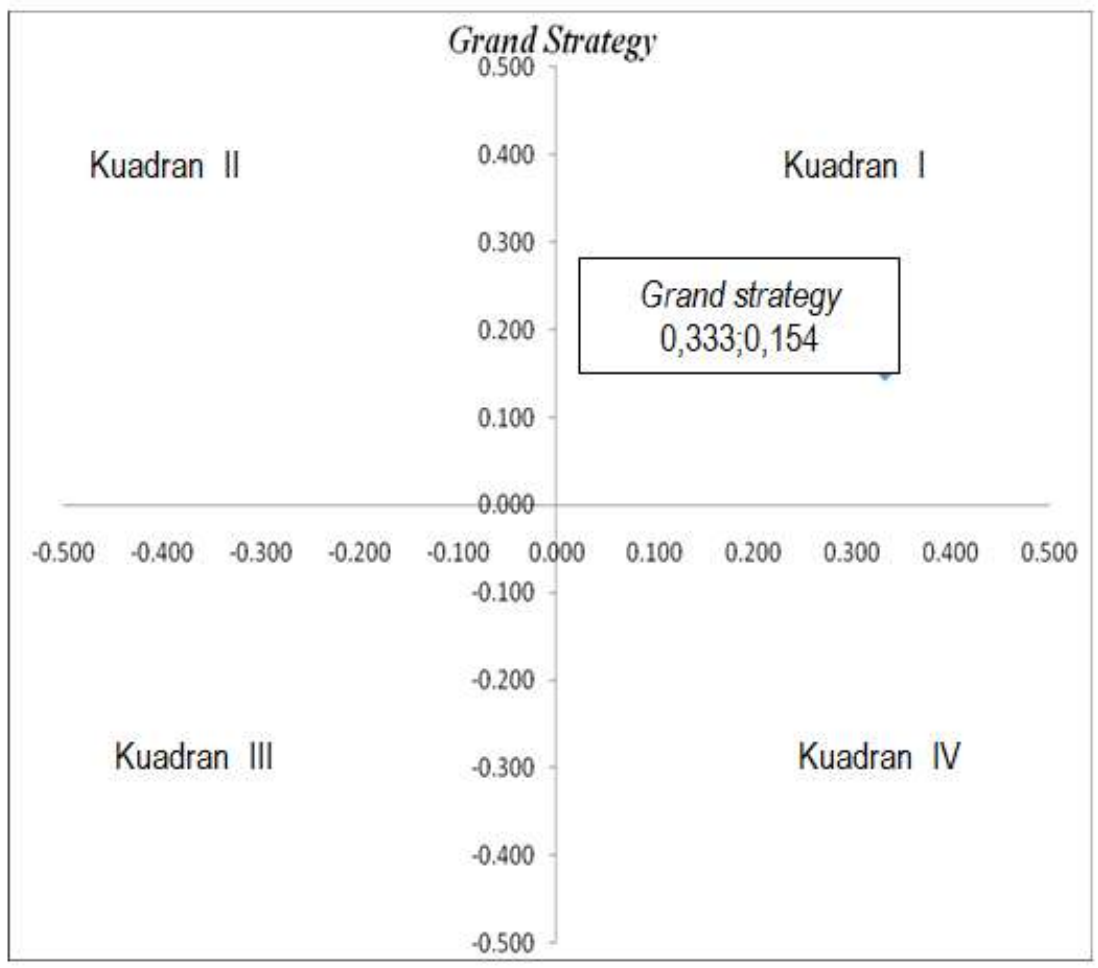

Gambar 3. Grand strategy

Posisi di kuadran I menandakan situasi yang sangat menguntungkan, dimana PPI Gebang mempunyai peluang dan kekuatan yang besar yang dapat dimanfaatkan untuk kemajuan PPI. Strategi yang harus diterapkan adalah progresif, artinya PPI Gebang dalam kondisi prima dan mantap sehingga sangat dimungkinkan untuk terus melakukan pembaharuan, memperbesar pertumbuhan dan meraih kemajuan secara maksimal.

\section{b. Rencana Strategi Pengelolaan PPI Gebang berdasarkan matrik SWOT}

Berdasarkan penentuan strategi melalui analisis matriks SWOT (Tabel 4) dan penentuan grand strategy (Gambar 3), maka rencana strategi dalam pengelolaan PPI Gebang adalah memanfaatkan sarana dan prasarana yang ada secara optimal. Strategi jangka pendek yang dapat ditempuh adalah menunjuk sebuah koperasi perikanan untuk melaksanakan kegiatan pelelangan. Keterbatasan dalam permodalan dapat diupayakan melalui pendekatan terhadap berbagai pihak yang bergerak dalam bidang permodalan. Melalui proses lelang diharapkan menjadi embrio bagi aktivitas perikanan di PPI Gebang.

Rencana strategis bagi pembangunan dan pengembangan PPI Gebang dapat ditempuh dengan membuat prioritas dalam perencanaan dan anggaran oleh instansi terkait baik yang berasal dari daerah maupun pusat. Dalam penerapan kebijakan pembangunan, diperlukan koordinasi dan konsolidasi antar instansi yang memiliki wilayah kerja di Kecamatan Gebang agar tidak muncul ego sektoral dan tumpang tindih antar kepentingan. Dengan demikian tujuan pengelolaan PPI Gebang untuk meningkatan kesejahteraan nelayan dapat tercapai. 


\section{SIMPULAN}

Kondisi fasilitas fungsional PPI Gebang cukup baik tetapi tidak dilengkapi dengan berbagai sarana untuk kepentingan navigasi dan kepelabuhanan. Tingkat pemanfaatan fasilitas pokok, fungsional, dan penunjang kurang. Potensi perikanan tangkap di PPI Gebang menunjukkan trend meningkat. Analisis pengelolaan cenderung sama kuat antara internal dan eksternal, dengan posisi di kuadran I. Strategi yang dapat diterapkan adalah mendukung kebijakan pertumbuhan yang agresif.

\section{REFERENSI}

Hendratmoko C. \& Marsudi H. (2010). Analisis tingkat keberdayaan sosial ekonomi nelayan tangkap di Kabupaten Cilacap. Jurnal Dinamika Sosial Ekonomi, 6(1): 17 hal.

Muflikhati I, Hartoyo, Ujang S, Ahmad F, \& Herien P. (2010). Kondisi sosial ekonomi dan tingkat kesejahteraan keluarga: Kasus di wilayah pesisir barat. Jurnal IImu Keluarga Dan konsumen, Januari 2010 Vol 3 No.1. Hal 1-10.

Noviyanti, R, Sugeng H.W, Eko S.W, Mulyono S.B \& Budi H. (2015). Analysis of self-capacity and education level of fishermen at Pasirbaru and Cidadap Villages, Sukabumi Regency. International Institute for Science, Technology and Education, Vol 5, No 21 (2015), p 177183.

Pemerintah Daerah Kabupaten Cirebon. (2009). Peraturan Daerah Kabupaten Cirebon Nomor 17 Tahun 2009 tentang Retribusi Tempat Pelelangan Ikan.

Rangkuti, F. (2016). Analisis SWOT: Teknik membedah kasus bisnis. Jakarta: Penerbit PT Gramedia Pustaka Utama.

Suherman, A.\& Dault A., (2009). Dampak sosial ekonomi pembangunan dan pengembangan pelabuhan perikanan nusantara (PPN) pengambengan jembrana Bali. Jurnal Saintek Perikanan, Vol. 4, No. 2, hal : 24-32. 